\title{
Struggle and Emerge: An Analysis of the Biopic, Documentary, and Drama Film Genres
}

\author{
Megan Parkyn
}

A historical film is fostered through the effective integration of cinematic language. It is through the development of cinematic components that film genres such as the drama, documentary, and biopic can be compared. The drama Flags of Our Fathers, ${ }^{1}$ the documentary We Were Children, ${ }^{2}$ and the biopic Walk the Line are comparable through the analysis of the directors' incorporation of specific film language. ${ }^{3}$ The similarities and differences among the film genres are evident in filmic components such as cinematography, lighting, and symbolism. Greater analysis exposes how film language contributes to the films historical significance.

It is through the greater analysis of each film that the impact of film language is revealed. In each of the films, the directors' purposefully utilized cinematography in order to enhance the impact of symbolism. For instance, high and low camera angles are utilized in order to develop an underlining contradiction between characters' struggles and their emergence from their adversity. This psychological battle is further depicted through the dichotomy of lighting on a character's face in a scene which visually represents the good and bad elements of humanity. This increased use of symbolism led to an enriched projection of colour in Flags of Our Fathers. ${ }^{4}$ The development of these colours directly impacts our sensory connection to these scenes. In We Were Children ${ }^{5}$ and Walk the Line, we experience the same use of film language. ${ }^{6}$

In the drama Flags of our Fathers, director Clint Eastwood, examines the role of the raising of the flag on Iwo Jima in the lives of three former combatants. ${ }^{7}$ At the time, the raising of the flag represented hope to the American people that the war in the Pacific would soon be over. American society thrust the men into the limelight of fame due to their roles in the iconic World War Two photograph. Eastwood explores the men's position in the war bonds campaign and their struggle to emerge from their valour. Each of the men walks the line between their heroism on the home front and their psychological scars from the battlefront.

The film utilizes flashback scenarios as a means of uncovering the short and longterm effects of war. Each of the men psychologically revisits the battlefront throughout the

\footnotetext{
${ }^{1}$ Flags of Our Fathers, directed by Clint Eastwood, (Paramount Pictures, 2006), DVD.

${ }^{2}$ We Were Children, directed by Tim Wolochatiuk, (Montreal: National Film Board of Canada, 2012), DVD.

${ }^{3}$ Walk the Line, directed by James Mangold, (Beverly Hills, CA: 20th Century Fox Home Entertainment, 2006), DVD.

${ }^{4}$ Flags of Our Fathers, DVD.

${ }^{5}$ We Were Children, DVD.

${ }^{6}$ Walk the Line, DVD.

${ }^{7}$ Flags of Our Fathers, DVD.
} 
film. Cinematographer Tom Stern depicts Iwo Jima in a "palette of pewter grays and pumice browns, highlighted by the red of flames, blood, and the flags." ${ }^{8}$ This muted background highlights the atrocities of war. It accentuates the experiences of the marines making the bright flashes of explosions and gunfire more profound. The cinematography focuses on the exploratory nature of the battlefield. Stern utilizes long frames in low and high angle dolly shots to develop the chaos and brutality of the frontline. In comparison, the war bond drive is characteristic of American fame with flashing cameras, "pounding drums, and cheering crowds" of publicity. ${ }^{9}$ Eye level camera angles are utilized to humanize the men. The combatants were exploited as heroes in order for the American government to fund the war effort. This allows the audience to observe the scene from the characters perspective. Stern, instead of placing the characters in low angle shots which inspire power and influence utilizes the eye level angle to stress the men's ambiguity as neither heroes nor victims. In these scenes, Stern also includes close-up angles which exaggerate the emotions of the characters. The war bonds campaign is not an easy enterprise for the men who believe that the real heroes are those that died on the battlefield. The varying emotions these men associate with the war and their renowned heroism are illustrated in these angles.

The photograph of the flag raising on Iwo Jima was not celebrated because "it was the best representation of war, but because it provided the strongest statement of American beliefs." ${ }^{10}$ The flag was a symbol of victory for the American people. It was an image that showed the labour of war and its resulting success instead of death. In the film, director Eastwood develops symbolism in order to represent the men's struggle with their heroism. The surviving marines view the photograph as a constant reminder to their military honour. The men are trapped in the public eye because of their heroism, but they view the real heroes as the men who fought and died on the battlefield. This tension between military fame and honour is encompassed in the metaphor of the bleeding cake. At a war bond event, the men are celebrated with cake representations of the photo which are drenched in raspberry syrup. This image represents the blood and honour of the men who died and the guilt of the surviving marines for their supposed valour. In the film We Were Children, we experience the suffering and emergence of children in the Residential School System. ${ }^{11}$

The documentary We Were Children chronicles the experiences of Glen Anaquod and Lyna Hart in Canadian Indian residential schools. ${ }^{12}$ From 1840 to 1996, First Nations children were forced to receive an education from government funded schools by law. These institutions were operated by various Christian groups who assimilated the children into their dominant Canadian culture. Director Tim Wolochatiuk examines the physical and psychological abuse that Anaquod and Hart experienced. The underlining theme of the film is characterized by Glen Anaquod's and Lyna Hart's ability to struggle and emerge from the Canadian government's abusive assimilation tactics. The resounding impacts on their lives

\footnotetext{
${ }^{8}$ Leo Braudy, "Flags of Our Fathers: Letters from Iwo Jima," Film Quarterly 60, no. 4 (2007): 17.

${ }^{9}$ Ibid, 19.

${ }^{10}$ Robert Hairman and John Lucaites, "Performing Civic Identity: The Iconic Photograph of the Flag Raising on Iwo Jima." Quarterly Journal of Speech 88, no. 4 (2002): 374.

${ }^{11}$ We Were Children, DVD.

12 Ibid.
} 
pushed them to persevere in the face of alcohol, drugs, and suicide. Hart states that the Canadian government was "trying to annihilate [them], but they couldn't. They only made [them] stronger and more determined." 13

In the documentary it is shown how the children's hair and clothes were identical and their names were stripped from them. The Indian residential schools are depicted in shades of black and brown in order to stress the dehumanization of the children within. Cinematographers Kim Bell and Jeremy Benning further this idea of dehumanization through their camera angles. The audience is subjected to high camera angles which look down upon the children from the nun's point of view. These angles portray the children as insignificant members of society. In contrast, the images of modern day Glen Anaquod and Lyna Hart are close-ups with minimal lighting. Their emotions are prominent on their faces, ensuring that the audience is connecting to and understanding the impact of their experiences. The delicate lighting is characterized by the shading of both Anaquod's and Hart's faces. The few shades of darkness on their faces reflect the residual psychological effects that both still experience. In Glen Anaquod's case, his face is half lighted and half dark which shows the two sides of his identity. The dark half of his face is subjected to the memories of the residential schools while the illuminated half represents his emergence from the resounding impact of life in the residential schools.

Glen Anaquod and Lyna Hart metonymously represent all of the First Nations boys and girls that were subjected to the Indian residential schools brutalities. Their lives in the institutions were filled with psychological and physical abuse. Director Wolochatiuk utilizes symbolism to represent the children's spiritual confinement. Hart's arrival at the residential school is filled with confusion and sorrow. Wolochatiuk uses the scene where the nuns pour Dichloro Diphenyl Trichloroethane (DDT) into the children's hair as a stepping stone into their mistreatment. The utilization of DDT develops the ideology that the Native children were viewed as pests to the Canadian government. Throughout the film, Anaquod's and Hart's emotional wellbeing is represented through symbolism. In the scene where Glen Anaquod is welcomed into the priest's home, his physical entrapment is characterized by the closed French doors, which also foreshadow his eventual confinement in the basement cellar. A red light symbolizes Hart's hell inside of the institution. In the film Walk the Line, the audience experiences Johnny Cash's descent into his personal hell. ${ }^{14}$

Director James Mangold examines the trials and tribulations of Johnny Cash's life in the biopic Walk the Line. ${ }^{15}$ John R. Cash was one of the most influential musicians of the twentieth century. His notable boom-chicka-boom music style chronicled the sorrow and hardships of his life. From an early age, Cash was engrossed in grief when his brother was unexpectedly killed in a table saw accident. His alcoholic father placed the blame of his brother's death on him, sending Cash into a spiral of depression. As Cash emerged in the music industry, his life was further complicated by the presence of June Carter and the pressure he felt to succeed. Cash's life was "clouded by pain" over the guilt of his brother's

\footnotetext{
${ }^{13}$ Frank Loreto, "We Were Children," Canadian Review of Materials 20, no. 14 (2013): 7.

${ }^{14}$ Walk the Line, DVD.

${ }^{15}$ Ibid.
} 
death, "his alcoholic father's mistreatment, and his drug abuse."16 Mangold develops a theme of redemption through Cash's relationship with June Carter and her increased influence on his spiritual beliefs.

Johnny Cash walked the line between his drug addictions and religion. He succumbed to his inner demons at the beginning of his music career, but ascended due to his increased reconnection to Christianity. Cash's saint and sinner tension is developed in the film through cinematography and lighting. Cinematographer Phedon Papamichael distinguished between Cash's two sides by utilizing low and high camera angles. At Cash's lowest points in his drug addiction, high camera angles are used to look down upon him. These angles diminish his power and develop the concept of his submissiveness and addiction to drugs and alcohol. It is during these scenes that Cash's face appears in darkness. The darkness over his face stresses his descent into hell through his sins of abuse and addiction. In contrast, when Cash reconnects with his Christian religion he is framed by windows that emit light which evoke a heavenly presence. This scene develops the idea that Cash has been saved by his Christian faith. Furthermore, when Cash sings at the San Quentin State Prison the camera captures him through low angles. In these scenes, Johnny Cash appears powerful and in control.

The underlining theme of redemption is illustrated through director James Mangold's purposeful decisions in the use of symbolism. Cash's journey to redemption was riddled with trials and tribulations. In the film, this journey is purposefully marked by the presence of a table saw. Cash's spiral into depression began with the death of his brother by the malfunction of a table saw at the family farm. From this point on, Johnny Cash's life is dictated by the cruel words of his father and the pressure of his music career. The slow ascension of Cash from his personal hell begins when he is awakened by the sound of saws after he passed out drunk in the woods. His life takes a dramatic turn from this point on in the film. The Carter family reintroduces him to the Christian religion and helps him in his detoxification from drugs. Cash's recovery is marked by June's gift of berries. The berries symbolize a pure and natural state which reflects Cash's clean body. The final ascension of Johnny Cash occurs when he is faced with the table saw at San Quentin. His final meeting with the saw represents his journey's closure. Merle Haggard stated that "seeing Cash perform in San Quentin [was] the turning point in his own redemption."17

Cinematography is an essential component of film making and the film language process. In all three of the films, the cinematographers chose to cultivate meaning through both lighting and camera angles. The films utilize one specific camera and lighting technique that shows the two sides of identity. This strategy is completed by shading one half of the characters face and illuminating the other. This technique is used in Walk the Line to show the tension between Johnny Cash's sinner and saint identity. ${ }^{18}$ In both of the other films, Glen Anaquod and Native American marine Ira Hayes are plagued by their past experiences in the residential schools and for Hayes also the battlefield. The hostility these

\footnotetext{
${ }^{16}$ Leigh Edwards, Johnny Cash: And the Paradox of American Identity. (Indianapolis: Indiana University Press, 2009), 49.

${ }^{17}$ Edwards, Johnny Cash, 92.

${ }^{18}$ Walk the Line, DVD.
} 
men feel between the resounding impacts and their societal identity is what clouds their faces.

Thematic undertones are produced in films through different cinematograph techniques. In each of the films, different camera angles are utilized in order to explore the underlining theme. Flags of Our Fathers cinematographer Stern uses an exploratory technique to capture the chaos of the battlefield. ${ }^{19}$ He utilizes long frames with high and low dolly shots to capture the emotion and military conduct of the American marines. In Walk the Line, cinematographer Papamichael uses a type of camera angle that subjects John R. Cash to the scrutiny of the public eye. ${ }^{20}$ Cash is presented in close-ups with high and low frames in order to capture his saint or sinner personality. The cinematography in We Were Children is developed in order to create a connection between the audience and Glen Anaquod and Lyna Hart. ${ }^{21}$ Cinematographers Bell and Benning utilize eye level close-ups in order for these connections to be established. In each of the film genres, the cinematographers utilized specific camera angles in order to further encompass the underlining theme of the picture.

The correlation between the Christian religion in the biopic and documentary is influenced by both directors' purposeful decisions in the use of symbolism. Mangold and Wolochatiuk utilize the technique in order to associate their characters with spiritual suppression and awakening. John R. Cash's and Lyna Hart's journeys through spirituality are purposefully marked by symbols. In We Were Children, Wolochatiuk marks the beginning of Hart's conflict with Christianity with a red light to suggest that she is trapped in hell. ${ }^{22}$ Cash's descent into his personal hell is represented by the saw. These characters struggles within spiritual confinement are defined by their turning points. Lyna Hart is rewarded by a nun for stealing food and feeding the hungry. This scene represents a return to hope for Hart. Johnny Cash's turning point occurs when June Carter gives him the berries. This scene is marked by white heavenly light and the organic and natural state of the berries. Cash is rejuvenated by the re-emergence of his Christian religion. Both Hart and Johnny Cash's journeys with spirituality conclude with a symbol. For Lyna Hart, the conclusion of her spiritual journey occurs when she daydreams of her horses. Her special place is defined by freedom and soon after she is released from the residential school. For Cash, the conclusion of his struggle with religion occurs when he views the table saw at San Quentin and his struggle ends with the very object that set it in motion.

In the film Flags of Our Fathers, the photograph of the flag rising on Iwo Jima is utilized as a recurring symbol of victory. ${ }^{23}$ Director Eastwood used the image in different mediums to stress the underlining theme of the movie and throughout the film the photograph is seen in newspapers. The popularization of the image further fuels the tension between military honour and fame. The development of one significant symbol throughout the film is unique to Flags of Our Fathers. ${ }^{24}$ This technique was not utilized

\footnotetext{
${ }^{19}$ Flags of Our Fathers, DVD.

${ }^{20}$ Walk the Line, DVD.

${ }^{21}$ We Were Children, DVD.

22 Ibid.

${ }^{23}$ Flags of Our Fathers, DVD.

${ }^{24}$ Flags of Our Fathers, DVD.
} 
within the other two films. Instead, directors Mangold and Wolochatiuk decided to develop other forms of symbolism. The combination of symbolism in both of these films shows the varying layers of John R. Cash's, Glen Anaquod's, and Lyna Hart's struggles with religion. In the biopic Walk the Line, Cash's constant tension with religion is caused by his father's mistreatment, Cash's alcohol and drug addictions, and his infidelity. ${ }^{25}$

Film language is used to create historical significance in the overall presentation of movies. In the films, Flags of Our Fathers, ${ }^{26}$ We Were Children, ${ }^{27}$ and Walk the Line film language is developed in order to create a rich historical document. ${ }^{28}$ This is seen specifically in Flags of Our Fathers through the exploratory nature of the cinematography. ${ }^{29}$ The emphasis that Stern places on the chaos of the battlefield creates historical accuracies. Camera angles and lighting are used to enhance the emotional magnitude of scenes or illustrate the films background. Directors purposefully integrate metaphors and symbols into films in order to further develop the underlining theme. In the biopic Walk the Line, this type of historical relevance is created through the use of symbolism to depict John R. Cash's saint and sinner juxtaposition..$^{30}$ Cash was famously known for his struggles with drugs and his passion for religion. It is through the integration of each of these components that a well-rounded film is established.

\footnotetext{
${ }^{25}$ Walk the Line, DVD.

${ }^{26}$ Flags of Our Fathers, DVD.

${ }^{27}$ We Were Children, DVD.

${ }^{28}$ Walk the Line, DVD.

${ }^{29}$ Flags of Our Fathers, DVD.

${ }^{30}$ Walk the Line, DVD.
} 
Bibliography

Braudy, Leo. "Flags of Our Fathers: Letters from Iwo Jima." Film Quarterly 60, no. 4 (2007): 16-23.

Edwards, Leigh. Johnny Cash: And the Paradox of American Identity. Indianapolis: Indiana University Press, 2009.

Flags of Our Fathers. Directed by Clint Eastwood. Paramount Pictures, 2006.

Hairman, Robert, and John Lucaites. "Performing Civic Identity: The Iconic Photograph of the Flag Raising on Iwo Jima." Quarterly Journal of Speech 88, no. 4 (2002): 363-392.

Loreto, Frank. “We Were Children." Canadian Review of Materials 20, no. 14 (2013): 1-7.

Walk the Line. Directed by James Mangold. Beverly Hills, CA: 20th Century Fox Home Entertainment, 2006.

We Were Children. Directed by Tim Wolochatiuk. Montreal: National Film Board of Canada, 2012. 